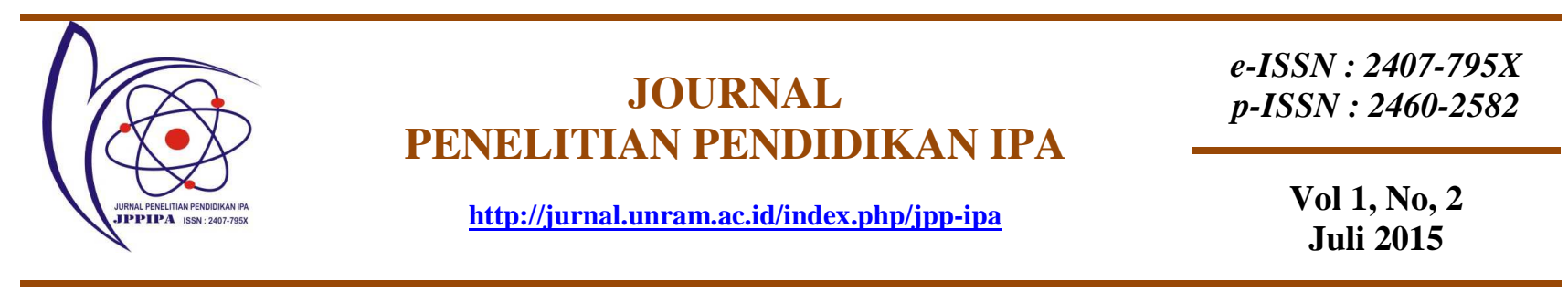

\title{
PENGEMBANGAN PERANGKAT PEMBELAJARAN MODEL 5E UNTUK MENINGKATKAN KEMAMPUAN BERPIKIR KRITIS SISWA
}

\author{
Muh.Nasir ${ }^{1}$, Wahab Jufri' ${ }^{2}$, Muhlis ${ }^{2}$ \\ Program Studi Magister Pendidikan IPA Program Pascasarjana Universitas Mataram ${ }^{123}$ \\ perahubima@gmail.com
}

\begin{abstract}
Key Words
5E Model,

Critical

Thinking Skills

Abstract

This study aims to develop of learning package 5E model and analyze the effect of its implementation on the differences in student's critical thinking and arguing skills. Development process follows $R$ \& D model by Dick and Carey. Research design follows pretest-posttest nonequivalent control group design. The population of this study was tenth graders of SMA 1 Woha Bima. Total population is 350 students from ten class. The sample was selected by simple random sampling technique and 131 students (four class) is obtained. X1 and X2 class are taught using the 5E models, while the X5 and X9 class with EEK models. Expert judgement results meet the criteria for the development of a very good result with an average value of 3.37. The results of experimental studies showed that: there is a difference in students' critical thinking in the experimental and control group $(t=3,501, p=0,001)$.
\end{abstract}

\begin{tabular}{|c|c|}
\hline Kata Kunci & Abstrak \\
\hline $\begin{array}{l}\text { Model 5E, } \\
\text { Kemampuan } \\
\text { Berpikir Kritis }\end{array}$ & $\begin{array}{l}\text { Penelitian ini bertujuan untuk mengembangkan perangkat pembelajaran model } 5 E \\
\text { dan menganalisis pengaruh implementasinya terhadap perbedaan kemampuan } \\
\text { berpikir kritis. Pengembangan perangkat pembelajaran dilaksanakan dengan } \\
\text { mengikuti langkah-langkah model Dick dan Carey. Desain penelitian eksperimen } \\
\text { menggunakan pretes-posttes non-equivalen control group desain. Populasi penelitian } \\
\text { eksperimen adalah siswa kelas X SMA Negeri } 1 \text { Woha Bima, sejumlah } 10 \text { kelas } \\
\text { dengan populasi } 350 \text { siswa. Sampel dipilih dengan tehnik simple random sampling } \\
\text { dari } 10 \text { kelas yang ada diambil } 4 \text { kelas sebagai sampel dengan jumlah sampel } 131 \\
\text { siswa. Kelas } X_{1} \text {, dan } X_{2} \text {, menerapkan perangkat model } 5 E \text { dan kelas } X_{5} \text {,dan } X_{9} \\
\text { menerapkan perangkat model EEK. Hasil uji ahli terhadap perangkat yang } \\
\text { dikembangkan memenuhi kriteria sangat layak dengan skor rata-rata sebesar } 3,37 \\
\text { dengan kategori sangat baik. Hasil penelitian eksperimen menunjukkan bahwa: } \\
\text { terdapat perbedaan yang signifikan kemampuan berpikir kritis siswa pada kelas } \\
\text { eksperimen dan kontrol }(t=3,501, p=0,001) \text {. }\end{array}$ \\
\hline
\end{tabular}




\section{PENDAHULUAN}

Dalam lampiran Permendiknas Nomor 22 Tahun 2006 tentang Standar Isi, dinyatakan pembelajaran biologi di SMA bertujuan agar siswa memiliki kemampuan sebagai berikut: (1) Membentuk sikap positif terhadap biologi dengan menyadari keteraturan dan keindahan alam serta mengagungkan kebesaran Tuhan Yang Maha Esa; (2) Memupuk sikap ilmiah yaitu jujur, objektif, terbuka, ulet, kritis dan dapat bekerjasama dengan orang lain; (3) Mengembangkan pengalaman untuk dapat mengajukan dan menguji hipotesis melalui percobaan, serta mengkomunikasikan hasil percobaan secara lisan dan tertulis; (4) Mengembangkan kemampuan berpikir analitis, induktif, dan deduktif dengan menggunakan konsep dan prinsip biologi; (5) Mengembangkan penguasaan konsep dan prinsip biologi dan saling keterkaitannya dengan IPA lainnya serta mengembangkan pengetahuan, keterampilan dan sikap percaya diri; (6) Menerapkan konsep dan prinsip biologi untuk menghasilkan karya teknologi sederhana yang berkaitan dengan kebutuhan manusia; 7) Meningkatkan kesadaran dan berperan serta dalam menjaga kelestarian lingkungan.

Salah satu upaya yang sedang dilakukan pemerintah dalam meningkatkan mutu pendidikan IPA adalah pembelajaran berpusat pada siswa dengan cara menekankan kegiatan inkuiri. Pada kegiatan inkuiri, siswa dilibatkan sebagai pelaku inkuiri secara aktif ketika melakukan observasi, eksplorasi, investigasi, pemodelan, perumusan hipotesis dan eksperimentasi terhadap berbagai gejala alam, sedangkan peran guru dalam pembelajaran IPA sebagai pemandu inkuiri (Anonim, 2011). Kegiatan inkuiri bertujuan untuk meningkatkan kemampuan berpikir. Kemampuan berpikir terdiri dari tiga yaitu berpikir tingkat tinggi, berpikir kompleks, dan berpikir kritis (Sutrisno, 2010). Kemampuan berpikir kritis merupakan salah satu bagian dari kemampuan berpikir tingkat tinggi, hal ini sesuai dengan pendapat Mangao (2011), bahwa kemampuan berpikir tingkat tinggi meliputi berpikir kritis, berpikir kreatif, berpikir analitik, pemecahan masalah, mensintesis, mengaplikasi, dan mengevaluasi.

Namun kenyataan yang terjadi pada lembaga-lembaga pendidikan di Indonesia, terutama pada jenjang sekolah dasar dan menengah adalah guru masih kurang memperhatikan aspek keterampilan berpikir dalam proses pembelajaran (Corebima, 2005). Siswa hanya difokuskan pada kegiatan menghafal materi pelajaran. Ketika siswa dihadapkan pada permasalahan yang terjadi di lingkungan sekitarnya, siswa kurang mampu menggabungkan pengetahuan yang dimilikinya untuk mencari penjelasan dan 
memberikan pendapat berupa solusi dari masalah tersebut menggunakan kemampuan berpikir kritis dan kemampuan berargumen.. Pelajaran biologi disekolah menengah dapat berperan sebagai sarana yang efektif untuk mengembangkan kemampuan berpikir kritis siswa. Kemampuan berpikir kritis merupakan salah satu komponen kecakapan hidup yang dapat dikembangkan melalui proses pembelajaran (Tim BBE, 2003). Melalui proses berpikir kritis, seseorang siswa dapat mengembangkan keterampilan menggali dan mengevaluasi informasi, kemampuan mempertimbangkan keputusan dan tindakan yang diambilnya, serta keterampilan menganalisis dan menyelesaikan masalah yang dihadapi dalam kehidupannya sehari-hari. Pengembangan kemampuan berpikir kritis seharusnya dapat dibantu oleh guru melalui pemilihan dan penerapan model pembelajaran yang dapat melibatkan siswa secara fisik dan mental dalam proses pembelajaran (Deming, 2004).

Salah satu model pembelajaran yang potensial untuk membantu siswa agar terlibat aktif dalam kegiatan belajar adalah model 5E (Bass et al, 2009). Model 5E merupakan suatu model yang terdiri dari lima tahapan, yaitu engage, exsplore, explain, elaborate, dan evaluate. Setiap tahap model $5 \mathrm{E}$ bertujuan untuk membangkitkan rasa ingin tahu siswa. Dasna dan Sutrisno (2005) menyatakan bahwa dalam model 5E siswa mengembangkan pemahamannya terhadap suatu konsep dengan kegiatan mencoba (hand-on activities) sebelum diperkenalkan dengan kata-kata melalui diskusi atau memperoleh informasi dari buku. Oleh sebab itu, model 5E juga dapat mengembangkan keterampilan proses siswa, memberi kesempatan kepada mereka melakukan percobaan sains secara langsung dan membuat pembelajaran bermakna. Model 5E juga dapat digunakan untuk melatih kemampuan berpikir kritis siswa. Hal tersebut didukung oleh hasil penelitian Fatimah (2012) yang menyatakan bahwa model pembelajaran Siklus belajar dapat meningkatkan kemampuan berpikir kritis siswa. Chankian (2012) menyatakan bahwa, siswa memiliki keterampilan sains yang lebih baik setelah penerapan pembelajaran model 5E. Selain itu, skor tes berpikir kritis sebagian besar siswa baik kelompok belajar tinggi dan rendah meningkat. Hasil yang baik diperoleh setelah penerapan model pembelajaran 5E dikarenakan model pembelajaran ini membuat siswa menjadi penasaran untuk belajar dan juga menekankan pada pengembangan kemampuan siswa.

Salah satu upaya untuk memfasilitasi perkembangan kemampuan berpikir kritis siswa sekolah menengah atas, maka dalam penelitian ini perlu dilakukan kegiatan pengembangan perangkat pembelajaran biologi model 5E, perangkat yang dikembangkan meliputi silabus, RPP, PKS, LHKS, instrument kemampuan berpikir kritis, dan 
kemampuan berargumen yang diintegrasikan dengan langkah-langkah pendekatan saintifik. Perangkat yang dikembangkan diharapkan dapat digunakan oleh guru sebagai media pengembangan yang efektif dan efisien. Selain itu, juga dapat digunakan oleh siswa sebagai sumber belajar sehingga dapat meningkatkan kualitas pembelajaran biologi, memotivasi siswa dalam belajar, dan ajang berlatih untuk belajar mandiri dalam memahami konsep-konsep biologi.

Berdasarkan atas permasalahan tersebut tujuan dari penelitian ini adalah menghasilkan Perangkat pembelajaran model 5E yang layak secara teoritis dan empiris dan juga mengetahui efektifitas implementasinya pada kemampuan berikir kritis siswa.

\section{METODE}

Perangkat pembelajaran model 5E dalam penelitian ini dikembangkan dengan mengikuti model Dick \& Carey (2001) yang terdiri dari sepuluh tahap dengan tujuan untuk menghasilkan prototype perangkat pembelajaran yang dapat meningkatkan aktifitas belajar siswa. Komponen perangkat yang dikembangkan terdiri atas Silabus, Rencana Pelaksanaan Pembelajaran (RPP), Petunjuk Kerja Siswa (PKS), Lembar Hasil Kerja Siswa (LHKS), instrumen kemampuan berpikir kritis dan instrumen kemampuan berargumen

Penelitian Eksperimen dilaksanakan di SMA Negeri 1 Woha Bima dengan menggunakan penelitian quasi eksperiment dengan desain Pre-test Post-Test ControlGroup. Pengambilan sampel dilakukan dengan teknik simple random sampling yaitu dari 10 kelas yang ada diambil 4 kelas sebagai sampel. Sampel penelitian berjumlah 131 orang siswa yang terdaftar pada semester II kelas X SMA Negeri 1 Woha Bima. Siswa di kelas $\mathrm{X}_{1}$ dan $\mathrm{X}_{2}$ diberikan pembelajaran dengan perangkat model $5 \mathrm{E}$ dan kelas $\mathrm{X}_{5}$ dan $\mathrm{X}_{9}$ diberikan pembelajaran dengan perangkat model EEK.

1. Analisis Data Kriteria Kelayakan Perangkat

Data kualitatif yang dikumpulkan berdasarkan penilaian kelayakan perangkat oleh ahli mencakup empat kategori yakni: 4 untuk kategori sangat layak, 3 untuk kategori layak, 2 untuk kategori kurang layak dan 1 untuk kategori tidak layak. Aspek-aspek yang diamati dan dinilai oleh validator berdasarkan instrumen lembar validasi yang dibuat peneliti pada masing-masing perangkat pembelajaran, yaitu: (a) Silabus, terdiri dari: isi yang disajikan, bahasa, dan Waktu; (b) Rencana Pelaksanaan Pembelajaran (RPP), terdiri dari: perumusan tujuan pembelajaran, isi yang disajikan, bahasa, dan waktu; dan (c) Lembar Hasil Kerja Siswa (LHKS), terdiri dari: isi yang disajikan dan bahasa. Selanjutnya, 
data penilaian kelayakan masing-masing perangkat pembelajaran ditabulasi dan dihitung rata-rata skor, kemudian diubah menjadi nilai dalam bentuk kriteria. Adapun kriteria tersebut dapat dilihat pada tabel 1. berikut ini Widoyoko (2012):

Tabel 1. Kriteria Nilai Rerata Total Skor Masing-Masing Komponen

\begin{tabular}{ccc}
\hline Nilai & Interval Skor & Kategori \\
\hline A & $3,26-4,00$ & Sangat Layak \\
B & $2,51-3,25$ & Layak \\
C & $1,76-2,50$ & Kurang Layak \\
D & $1,00-1,75$ & Tidak Layak \\
\hline
\end{tabular}

Nilai kelayakan produk dalam penelitian ini ditetapkan minimal "B" kriteria layak. Dengan demikian, hasil penilaian validator jika memberi hasil akhir "B" atau layak, maka produk pengembangan layak digunakan dalam uji coba produk. Namun sebelum di uji coba, terlebih dahulu masing-masing perangkat pembelajaran tersebut di revisi sesuai dengan komentar/saran yang dikemukakan diakhir lembar validasi perangkat

2. Analisis Data Kemampuan Berpikir Kritis

Data post-test kemampuan berpikir kritis yang diperoleh ditabulasi kemudian dihitung nilai rata-ratanya. Data post-test kemampuan berpikir kritis ini digunakan untuk menguji hipotesis. Uji hipotesis dilakukan untuk mengetahui: Apakah ada perbedaan kemampuan berpikir kritis siswa yang belajar dengan perangkat pembelajaran model $5 \mathrm{E}$ dengan siswa yang belajar dengan perangkat pembelajaran model EEK. Uji hipotesis penelitian menggunakan uji-t dengan bantuan program komputer SPSS 20 for windows pada taraf signifikan 5\%. Kriteria pengujian hipotesis: Ho ditolak apabila $t_{\text {hitung }}>t_{\text {tabel }}$ atau nilai $\mathrm{p}>0,05$ maka Ho diterima, demikian sebaliknya jika $\mathrm{p}<0,05$ maka Ho ditolak.

\section{HASIL DAN PEMBAHASAN}

Perangkat pembelajaran yang terdiri atas Silabus, Rencana Pelaksanaan Pembelajaran (RPP), Petunjuk Kerja Siswa (PKS), Lembar Hasil Kerja Siswa (LHKS) dan instrumen yang digunakan dalam penelitian, sebelum digunakan telah mengalami proses validasi oleh 3 orang ahli. Hasil validasi ahli terhadap perangkat pembelajaran yang dikembangkan sebagai berikut:

Tabel 2 Rekapitulasi Hasil Penilaian Perangkat Pembelajaran

\begin{tabular}{llcc}
\hline No & \multicolumn{1}{c}{ Perangkat Pembelajaran } & Nilai Rata-rata & Kualifikasi \\
\hline 1. & Silabus & 3.30 & Sangat layak \\
2. & Rencana Pelaksanaan Pembelajaran & 3.37 & Sangat layak \\
3. & Petunjuk Kerja Siswa & 3.30 & Sangat layak \\
\hline
\end{tabular}




\begin{tabular}{llll}
\hline 4. & Lembar Hasil Kerja Siswa & 3.50 & Sangat layak \\
5. & Tes Kemampuan Berpikir Kritis & 3.42 & Sangat layak \\
6. & Tes Kemampuan Berargumen & 3.33 & Sangat layak \\
\hline & Rata-rata & 3,37 & Sangat layak \\
\hline
\end{tabular}

Hasil data pada Tabel 2. menunjukkan bahwa skor rata-rata perangkat pembelajaran yang dikembangkan sebesar 3,37, skor ini berada pada kategori sangat layak, ini berarti bahwa seluruh perangkat pembelajaran yang dikembangkan layak digunakan dalam penelitian.

Hasil ini sesuai dengan Indriyani (2013), Purnama (2014) menunjukkan bahwa RPP yang dikembangkan baik dan layak digunakan dengan. Hasil penelitian serupa oleh Sari (2013) menunjukan bahwa hasil pengembangan LKS model 5E memiliki kategori baik dan layak. Indriyani (2013) menunjukan bahwa LKS ditinjau dari aspek kelayakan isi, aspek kebahasaan, aspek penyajian dan aspek kegrafikan secara keseluruhan baik dan layak digunakan. Shofiyah (2013) menunjukkan bahwa LKS efektif untuk menumbuhkan penalaran ilmiah siswa.

\section{Kemampuan Berpikir Kritis}

Data kemampuan berpikir kritis yang dideskripsikan dalam penelitian ini adalah skor rata-rata yang diperoleh subjek penelitian dari tes kemampuan berpikir kritis terkait materi ekologi kelas X SMA. Skor rata-rata kemampuan berpikir kritis kemudian diklasifikasi kedalam 5 kategori yaitu, Nilai 40,00-51,40 dikategorikan Sangat Kurang, 51,41-62,90 kategori Kurang, 62,91-74,30 kategori Sedang, 74,31-85,70 kategori Baik, dan $\geq 85,71$ Gronlund dan Linn dalam Jufri, (2010). Rata skor kemampuan berpikir kritis siswa sebagai efek dari pembelajaran dengan perangkat pembelajaran model 5Eadalah sebagai berikut:

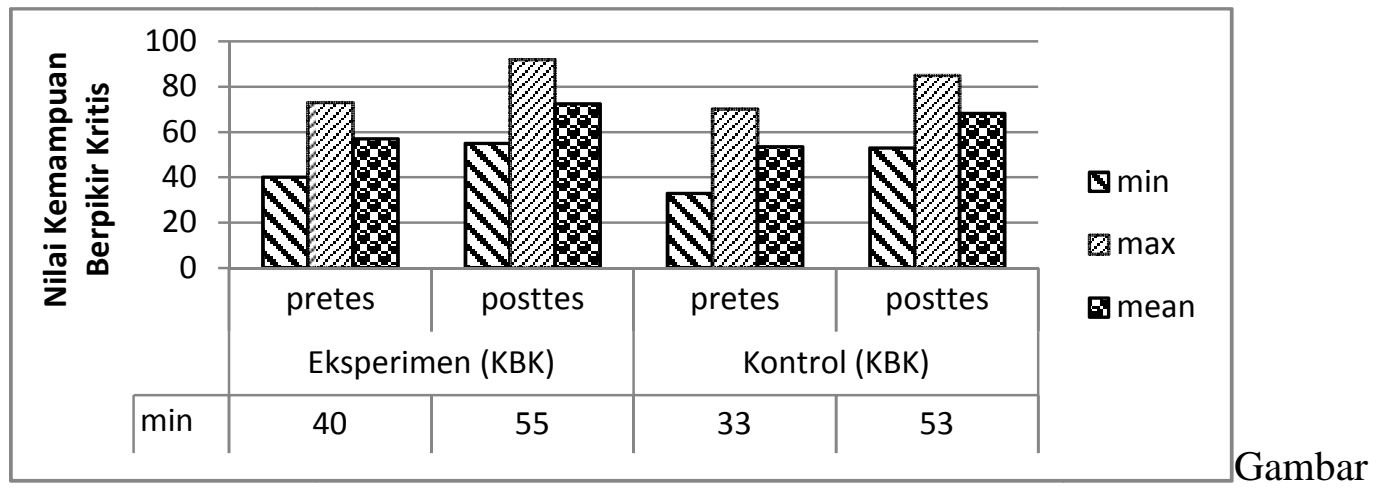

1. Diagram Batang Rerata Skor Kemampuan Berpikir Kritis 
Berdasarkan Gambar 1 dapat diketahui bahwa perangkat pembelajaran model 5E yang diterapkan pada kelas eksperimen mempunyai kecenderungan untuk meningkatkan kriteria skor kemampuan berpikir kritis, hal ini terlihat dari rata-rata skor pretes kemampuan berpikir kritis siswa sebesar 57 dengan kategori kurang, kemudian mengalami peningkatan setelah dilakukan pembelajaran dengan model $5 \mathrm{E}$ sebesar 72 , skor ini berada pada kategori sedang. Selanjutnya rerata skor kemampuan berpikir kritis pada kelas kontrol yang menggunakan perangkat pembelajaran model EEK juga mengalami peningkatan dari 54 menjadi 68 dengan kategori kurang menjadi 68 pada kategori sedang.

Sebaran persentase peningkatan kemampuan berpikir kritis siswa pada tiap kategori ditunjukkan pada tabel 3 berikut:

Tabel 3 Persentase Sebaran Nilai Kemampuan Berpikir Kritis Berdasarkan N-Gain

\begin{tabular}{|l|c|c|c|c|c|c|c|}
\hline \multirow{2}{*}{ Perlakuan } & \multirow{2}{*}{$\mathrm{N}$} & \multicolumn{2}{|c|}{ Tinggi } & \multicolumn{2}{c|}{ Sedang } & \multicolumn{2}{c|}{ Rendah } \\
\cline { 3 - 8 } & & Jumlah & Persentase & Jumlah & Persentase & Jumlah & Persentase \\
\hline Eksperimen & 66 & 1 & $1,52 \%$ & 41 & $62,12 \%$ & 24 & $36,36 \%$ \\
\hline Kontrol & 65 & 0 & $0,0 \%$ & 30 & $46,15 \%$ & 35 & $53,85 \%$ \\
\hline
\end{tabular}

Tabel 3 menunjukkan bahwa walaupun rata-rata $\mathrm{N}$-gain antara kelas eksperimen dan kelas kontrol mempunyai kategori sama yaitu sedang, tetapi frekuensi siswa pada kategori n-gain tinggi sebanyak $1(1,52 \%)$ siswa sedangkan pada kelas kontrol tidak ada siswa yang berkategori n-gain tinggi, begitu juga pada kategori sedang pada kelas eksperimen jumlah siswa lebih banyak dibanding kelas kontrol yaitu sebanyak 41 $(62,12 \%)$ siswa untuk kelas eksperimen dan 30 (46,15\%) siswa untuk kelas kontrol, sementara pada kategori rendah, jumlah siswa pada kelas eksperimen lebih sedikit dibandingkan dengan kelas kontrol yaitu sebanyak 24 (36,36\%) siswa untuk kelas eksperimen dan $35(53,85 \%)$ untuk kelas kontrol. Sehingga dapat disimpulkan bahwa peningkatan kemampuan berpikir kritis siswa kelas eksperimen lebih tinggi daripada kelas kontrol.

Meningkatnya kemampuan berpikir kritis dalam penelitian ini sesuai dengan pendapat Ennis dalam Splitter (1992) serta Fogarty dan McTighe (1993) bahwa berpikir kritis merupakan cara berpikir reflektif yang masuk akal atau berdasarkan nalar untuk menentukan apa yang akan dikerjakan dan diyakini. Di dalam proses berpikir berlangsung kejadian menganalisis, mengkritik, dan mencapai kesimpulan berdasar pada inferensi atau pertimbangan yang seksama (Ibrahim dan Nur, 2000). Disampaikan oleh Diestler (1994) bahwa dengan berpikir kritis, orang menjadi memahami argumentasi perbedaan berdasarkan perbedaan nilai, memahami adanya inferensi dan mampu menginterpretasi, 
mampu mengenali kesalahan, mampu menggunakan bahasa dalam berargumen, menyadari dan mengendalikan egosentris dan emosi, dan responsif terhadap pandangan yang berbeda.

Kemampuan berpikir kritis merupakan proses kognitif dan aktivitas mental untuk memperoleh pengetahuan. Liliasari (2000) menyatakan bahwa kemampuan berpikir kritis merupakan aktivitas berpikir tingkat tinggi. Berpikir kritis ini mengaktifkan kemampuan melakukan analisis dan evaluasi bukti, identifikasi pertanyaan, kesimpulan logis, memahami implikasi argumen (Friedrichsen, 2001). Lebih lanjut McMurarry et al (2005) menyampaikan bahwa berpikir kritis merupakan kegiatan yang sangat penting untuk dikembangkan di sekolah, guru diharapkan mampu merealisasikan pembelajaran yang mengaktifkan dan mengembangkan kemampuan berpikir kritis pada siswa. Bahkan Schaferman (1999) menyatakan bahwa perencanaan pembelajaran IPA oleh guru untuk pengembangan kemampuan berpikir kritis siswa adalah keharusan. Hal ini didukung oleh penyataan Friedrichsen (2001) bahwa kemampuan berpikir kritis seyogyanya dikembangkan sejak usia dini. Selanjutnya, disampaikan oleh Ennis (1993) bahwa evaluasi terhadap kemampuan berpikir kritis antara lain bertujuan untuk mendiagnosis tingkat kemampuan siswa, memberi umpan balik keberanian berpikir siswa, dan memberi motivasi agar siswa mengembangkan kemampuan berpikir kritisnya

Hasil uji normalitas data dengan statistik parametrik Kolmogorov - Smirnov tes menunjukkan bahwa data pada seluruh perlakuan berdistribusi normal. Demikian pula dengan hasil ujihomogenitas data dengan Levene's test menunjukkan bahwa koefisien statistik Leven's untuk kemampuan berpikir kritis adalah 0,80. Angka tersebut lebih besar dari 0,05 dan memberikan makna bahwa varian data pada semua perlakuan adalah homogen, sehingga data dapat dianalisis dengan tehnik uji-t. Hasil uji-t terhadap kemampuan berpikir kritis dari dua perlakuan eksperimen dan kontrol disajikan pada tabel 4.

Tabel 4 Hasil Uji-t Kemampuan Berpikir Kritis

\begin{tabular}{llccccc}
\hline & Df & $\begin{array}{c}\text { Mean } \\
\text { Diference }\end{array}$ & $\begin{array}{c}\text { Std Error } \\
\text { Diference }\end{array}$ & T & $\begin{array}{c}\text { Sig } \\
\text { (2-talled) }\end{array}$ \\
\hline Posttes_KBK & $\begin{array}{l}\text { equal variances } \\
\text { assumed } \\
\text { equal variances } \\
\text { not assumed }\end{array}$ & 129 & 4,30093 & 1,22834 & 3,501 & 0,001 \\
& 126,21 & 4,30093 & 1,22745 & 3,504 & 0,001 \\
\hline
\end{tabular}

Data pada tabel 4 menunjukkan bahwa ada perbedaan kemampuan berpikir kritis siswa yang belajar dengan perangkat pembelajaran model 5E dengan siswa yang belajar 
dengan perangkat pembelajaran model EEK di SMA Negeri 1 Woha $\left(t_{\text {hitung }}=3,501\right.$ dan $p=$ $0,001)>0,05$. Hasil ini mengindikasikan bahwa kemampuan berpikir kritis siswa yang belajar dengan perangkat model $5 \mathrm{E}$ berbeda signifikan dengan siswa yang belajar dengan perangkat model EEK.

\section{KESIMPULAN}

1. Perangkat pembelajaran model 5E yang dikembangkan meliputi silabus, RPP, LKS (PKS dan LHKS), instrumen kemampuan berpikir kritis dan instrumen kemampuan berargumen. Karakteristik silabus yang dikembangkan terletak pada kegiatan pemberian pengalaman belajar siswa yang memuat tahapan model 5E (Engage, Explore, Explain, Elaborate, dan Evaluasi) dan memuat indikator pembelajaran kemampuan berpikir kritis. Karakteristik RPP terletak pada kegiatan pembelajaran yang disusun berdasarkan tahapan model pembelajaran 5E yang memuat langkahlangkah saintifik (mengamati, menanya, mencoba, menalar, menyimpulkan dan menyajikan) untuk meningkatkan kemampuan berpikir kritis siswa. Karakreistik LKS (PKS dan LHKS) yaitu materi pengamatan memuat konteks permasalahan yang dekat dengan kehidupan di sekitar siswa, dan dirancang mengikuti tahapan model 5E, komponen PKS meliputi judul pengamatan, masalah pengamatan, tujuan, prosedur pengamatan yang memuat alat dan bahan dan langkah kerja, bahan diskusi, dan kesimpulan. Sementara Instrumen kemampuan berpikir kritis memiliki karakteristik yaitu memuat indikator kemampauan berpikir kritis. Hasil penilaian perangkat pembelajaran yang dikembangkan adalah sangat layak untuk digunakan dalam pembelajaran biologi khususnya pada materi ekologi.

2. Ada perbedaan kemampuan berpikir kritis siswa yang belajar dengan perangkat pembelajaran model $5 \mathrm{E}$ dengan siswa yang belajar dengan perangkat pembelajaran model EEK di SMA Negeri 1 Woha. 


\section{DAFTAR PUSTAKA}

Anonim, 2011. Mata Pelajaran Science. Kementrian Pendidikan Nasional. Direktorat Pendidikan Dasar. Direktorat Pembina Sekolah Menengah Pertama. Jakarta: Quality Endorsed Company.

Bass, J. EContat, T.L. and Carin, A. A. 2009. Teaching Science as Inquiry. Boston: Pearson.

Chankian, Jeeraporn, Adisak Singseewo, dan Penkae Thamsananupap. 2012. Science Curriculum Development on Environmental Conservation, with an Emphasis on the Promotion of Critical Thinking Skills for Mathayomsuksa 1 Students. European Journal of Scientific Research, (Online): Vol.67 Nomor 4, (http://www.europeanjournalofscientificresearch.com/ISSUES/

EJSR_67_4_03.pdf, diakses 4 Desember 2012).

Corebima, A.D. 2005. Keterampilan Proses: Pemberdayaan dan Asesmen. Makalah disajikan dalam Workshop bagi Mahasiswa dan Guru Pelaksana PTK A2 di Batu, Malang, 24 Juni 2005

Deming, J.C., and M.S. Cracolice. 2004. Learning How to Think. The Science Teacher.

Dick,W, Carey, L, Carey, J.O. 2001. The Systematic Design of Instruction. United States: Addison-Wesley Education Publisher.

Diestler, S. 1994. Becoming a Critical Thinker A User-Friendly Manual. New York: Macmillian Publishing Company

Ennis, R.H. 1993. Critical Thinking Assesment. Journal Theory and Practice. 32(3) Summer 1993. Ohio: Ohio State University

Fatimah, N. 2012. Penerapan Model Pembelajaran Learning Cycle 5E dalam Mata Pelajaran Matematika untuk Meningkatkan Kemampuan Berpikir Kritis Siswa SMA. Skripsi tidak diterbitkan. Bandung: Jurusan Pendidikan Matematika FPMIPA UPI

Fogarty, R. and McTighe, J. 1993. Critical Thinking Assesment. Journal Theory and Practice, 32(3) Summer 1993. Ohio: Ohio State University.

Friedrichsen, P.M. 2001. A Biology Course for Prospective Elementary Teachers. The American Biology Teacher. Vol. 63 (8) : 562-568

Gronlund, N.E \& R.L Linn., 1990. Measurement and Evaluation in Teaching. $6^{\text {th }}$. Ed. New York: MacMillan Publishing Company.

Indriyani.,R.I. 2013. Pengembangan LKS Berbasis Siklus Belajar (Learning Cycle) 7E Untuk Meningkatkan Hasil Belajar Dan Mengembangkan Kemampuan Berpikir Kritis Pada Siswa SMA Kelas X Pokok Bahasan Elektromagnetik. Tesis. FKIP.Yogyakarta. 
Jufri, A.W. dan Jekti, S. D. D. 2010. Efektifitas Pembelajaran Sains Berbasis Inkuiri dengan Strategi Kooperatif dalam Meningkatkan Keterampilan Berpikir Siswa SMP. Jurnal Pendididkan dan Pembelajaran, vol 17, No 2. Oktober 2010.

Lawson, A, E. 1978. Development and Validation of The classroom Test of Formal Reasoning. Journal of Reseach in Science Teaching, 15(1).

Liliasari. 2000. Model Pembelajaran untuk Meningkatkan Keterampilan Berpikir Konseptual Tingkat Tinggi Calon Guru IPA. Prosiding Seminar Nasional, Malang, 23 Pebruari 2000. Malang: Ditjen Dikti Depdiknas-JICA-IMSTEP. Hlm 135-140

Mangao, D. D. 2011. Enhancing Higher Order Thinking Skill in Secondary ScienceVia Information and Communication Technology. Penang. Southeast Asian Minister of Education Organizasion. Regional Center for Education in Science and Mathematics.

McMurarry, M.A. Beisenherz and Thompson, B. 1991. Reliability and Concurrent Validity of A Measure of Critical Thinking Skills in Biology. Journal of Research in Science Teacher, 28(2): 183-192

Nur, M., Ibrahim. 2000. Pegajaran Berpusat kepada Siswa dan Pendekatan Konstruktivis dalam Pengajaran. Surabaya: UNESA-University Press.

Permendiknas Nomor 22 Tahun 2006 tentang Standar Isi.

Purnama Sari. Ismono, Laili. 2014. Pengembangan Perangkat Pembelajaran Dengan Model Learning Cycle Pada Materi Suhu Dan Perubahannya Untuk Siswa SMP Kelas VII. Jurnal Unesa Vol 2, No 02.

Sari.,S.I 2013. Pengembangan Lembar Kegiatan Siswa Beroreantasi Model Learning Cycle 5E pada Materi Ekosistem. Jurnal Unesa BioEdu vol.2/No.1/Januari.

Schaferman, S.D. 1999. An Introduction to Critical Thinking, (Online), (http://www.freeinquiry,com/critical.thinking.html, diakses 25 Agustus 2014

Shofiyah, N., Supardi, Jatmiko. 2013. Mengembangkan Penalaran Ilmiah (Scientific Reasoning) Siswa Melalui Model Pembelajaran 5E pada Siswa Kelas X SMAN 15 Surabaya. Jurnal Pendidikan IPA Indonesia.

Splitter, L.J., 1992. Critical Thinking: What, Why, When, and How. Australia: Australian Council for Education Research

Sutrisno dan Dasna, I.W. 2005. Model-model Pembelajaran Konstruktivistik dalam Pengajaran Sains/ Kimia. Malang: Universitas Negeri Malang

Sutrisno, J. 2010. Menggunakan Keterampilan Berpikir Untuk Meningkatkan Mutu Pembelajaran. (Online): (http//www.scribd.com/doc/54977805/ artikel-erlangga, dakses 15 Desember 2012). 
TIM BBE. 2003. Pola Pelaksanaan Pendidikan Kecakapan Hidup, Melalui Pendekatan Pendidikan Berbasis Luas. Lembaga Pengabdian Masyarakat UNESA_JATIM: SIC. Depdiknas.

Widoyoko E.P. 2012. Tehnik Penyusunan Instrumen Penelitian. Yogyakarta: Pustaka Pelajar. 